\title{
ON THE GLUCOKINASE ACTIVITY OF EXTRACTS FROM NORMAL AND ATROPHIC MUSCLES*
}

\author{
by \\ T. GERRITSEN * \\ Laboratory of Physiological Chemistry, University, Utrecht (Netherlands)
}

Little is known about the relative glucokinase content of various muscles. We have therefore carried out determinations of the glucokinase activity of extracts from muscles of various species as an introduction to work on the chemical changes appearing in muscles of patients suffering from muscle diseases. Besides the distribution of glucokinase in normal muscles, the influence of denervation on the glucokinase content of the gastrocnemius and the quadriceps femoris of the rabbit, and the activity of extracts from atrophied human muscles were also studied.

No difficulties were encountered during the investigation of muscles of the rat, the guinea-pig, the rabbit, and the chicken, and of human subjects. The work on pigeon muscles, however, gave puzzling results, which could not be satisfactorily interpreted. They were useful, however, in showing that caution should be exercised when interpreting the results obtained with the muscles of the other species mentioned.

\section{EXPERIMENTAL PART}

\section{METHODS AND MATERIALS}

The method of extraction of glucokinase from the muscles was based on that given by CoLowick, CoRI AND SLEIN1. The animals were decapitated (larger ones under ether narcosis, smaller ones without narcosis) and the required muscles were immediately excised and cooled on ice. All further manipulations were carried out in the cold room (temp. about $0^{\circ} \mathrm{C}$ ). After mincing with scissors in about 4 minutes the brei was ground with sand in a chilled mortar ( 1 minute) and stirred for 4 minutes with 3 volumes of water. (If this amount of water was used the extracts had activities situated in the range required for a determination. Extracts with too high activity for direct determination cannot be diluted, see p. 473). The tissue debris was spun down by 5 minutes' centrifuging at $600 \mathrm{~g}$. The supernatant was recentrifuged for 3.5 minutes at $18000 \mathrm{~g}$ in order to obtain a perfectly clear extract with little ATP-ase activity.

The glucokinase activity was determined within 2 hours after preparing the extract. According to $\mathrm{KUN}^{2}$ the activity would increase in 2 hours at $0^{\circ} \mathrm{C}$. Though we did not observe such an increase, we could neither detect a diminution of the activity during this time.

The determinations were carried out according to the glucosimetric method of CoLowick, CorI AND SLEIN ${ }^{1}$.

Reaction vessels with a side bulb were used; $0.8 \mathrm{ml}$ muscle extract and $\mathrm{I} .2 \mathrm{ml} \mathrm{I} / 7 M$ veronalacetate buffer of $\mathrm{pH}$ between 8 .0 and 8.3 , containing $\mathrm{MgCl}_{2}(0.017 M)$ were placed in the main compartment. The side bulb was flled with $0.1 \mathrm{ml} 2.5 \%$ glucose solution, 0 . $15 \mathrm{ml}$ of a solution containing

* This work forms part of the investigations on the chemistry of muscle diseases by $H . G, K$. Westenbrink and co-workers, supported by grants from the Prince Bernhard Foundation and the Netherlands Organisation for Pure Research (Z.W.O.). Requests for reprints should be addressed to Prof. Westenbrink.

* Present address: S. A. Institute for Medical Research, Johannesburg (South Africa). 
$\mathrm{KCl}(0.9 M)$ and $\mathrm{KHCO}_{3}(0.05 M)$, and $0.1 \mathrm{ml}$ o. I $M$ potassium salt of ATP. After Io minutes' equilibration in the water bath of $27^{\circ} \mathrm{C}$ the contents of main compartment and side bulb were mixed. The $\mathrm{pH}_{\mathrm{H}}$ of the veronal-acetate buffer in the main compartment was such that the final pH of the complete mixture was 7.4 to 7.5 , the optimal $\mathrm{PH}$ for muscle glucokinase action.

Glucose was determined according to NeLson's method immediately, and ro minutes after mixing. The glucokinase activity, causing the disappearance of I $\gamma$ glucose from the reaction mixture in these ro minutes, was called the glucokinase unit (GU).

Each reaction mixture contained $0.8 \mathrm{ml}$ muscle extract; I $\mathrm{g}$ muscle contains about $0.8 \mathrm{ml}$ water. Therefore upon extraction of $\mathrm{I}$ g muscle with $3 \mathrm{ml}$ water the number of $\mathrm{GU}$ per $\mathrm{g}$ muscle was calculated by multiplying the number of GU per reaction mixture by $3.8 / 0.8$.

Every glucokinase determination was carried out in duplicate. Therefore for each determination four reaction vessels had to be used, two for the glucose determination immediately after mixing and the other two for the determination ro minutes later.

Optimal reaction rates were obtained with $2500-2700 \gamma$ glucose. $2500 \gamma$ was always added to a reaction mixture. As $0.8 \mathrm{ml}$ muscle extract appeared to contain amounts of reducing substance (part of which will certainly have been glucose) equivalent to 50-300 $\gamma$ glucose, the total amount of glucose at the beginning of an experiment has sometimes been a little higher than optimal, without notably depressing the reaction rate, however.

ATP was prepared from rabbit muscle according to the (slightly modified) method of DouncE et $a l .{ }^{5}$ and purified according to BAILE $\mathrm{Y}^{4}$. The purity was about $97 \%$. Impurities present in various commercial preparations appeared to have a depressing effect on the glucokinase activity.

In the range of molarity from 0.001 to 0.016 the rate of the reaction appeared to be independent of the ATP concentration. (See also WIEBELHAUS AND LARDY ${ }^{3}$ ).

Extracts and solutions were always prepared with glass-distilled water.

The accuracy of the method used appears from the results of series of determinations carried out in 4 to 8 portions of minced muscle (see Table I).

\section{TABLE I}

EXPERIMENTAL ERROR OF THE GLUCOKINASE DETERMINATION

Results expressed in GU (glucose units) per $g$ tissue

\begin{tabular}{|c|c|c|}
\hline $\begin{array}{l}\text { Serratus } \\
\text { (human) }\end{array}$ & $\begin{array}{c}\text { Mixed leg } \\
\text { muscles (rat) }\end{array}$ & $\begin{array}{c}\text { Quadriceps } \\
\text { femoris (rabbit) }\end{array}$ \\
\hline $\begin{array}{r}\text { I I } 40 \\
920 \\
\text { I000 } \\
\text { I050 }\end{array}$ & $\begin{array}{l}\text { I } 520 \\
\text { I } 410 \\
\text { I } 57^{\circ} \\
\text { I330 }\end{array}$ & $\begin{array}{l}720 \\
590 \\
740 \\
850 \\
820 \\
640 \\
710 \\
830\end{array}$ \\
\hline $\begin{array}{c}\text { Mean } \\
\text { ro3o } \pm 90\end{array}$ & $\begin{array}{c}\text { Mean } \\
1460 \pm I 10\end{array}$ & $\begin{array}{c}\text { Mean } \\
7 \text { Io } \pm 90\end{array}$ \\
\hline
\end{tabular}

\section{RESULTS}

\section{Normal muscles}

\section{Rabbit}

White leg muscle (vastus lateralis), red leg muscle (vastus intermedius + semitendineus + soleus), a muscle from the back (erector trunci), the heart muscle, the stomach muscle and the muscle of the diaphragm were investigated. The results of these determinations are assembled in Table II. It is evident from these figures that the method employed was not sufficiently accurate to demonstrate a difference between the various skeletal muscles, if such a difference exists. Therefore the mean and the standard 
TABLE II

GLUCOKINASE ACTIVITY (GU PER G TISSUE) OF EXTRACTS FROM NORMAL RABBIT MUSCLES

\begin{tabular}{c|c|c|c|c|c|c}
$\begin{array}{c}\text { Rabbit } \\
\text { No. }\end{array}$ & $\begin{array}{c}\text { White } \\
\text { leg muscle }\end{array}$ & $\begin{array}{c}\text { Red } \\
\text { leg muscle }\end{array}$ & $\begin{array}{c}\text { Muscle } \\
\text { from back }\end{array}$ & $\begin{array}{c}\text { Heart } \\
\text { muscle }\end{array}$ & $\begin{array}{c}\text { Stomach } \\
\text { muscle }\end{array}$ & $\begin{array}{c}\text { Diaphragm } \\
\text { muscle }\end{array}$ \\
\hline $\mathrm{I}$ & 670 & 620 & 640 & 910 & 240 & I 10 \\
2 & 730 & 690 & 770 & 990 & 400 & 140 \\
3 & 930 & 950 & 860 & 1520 & 520 & I60 \\
4 & 320 & - & - & 880 & - & - \\
5 & 900 & - & - & 1260 & - & - \\
6 & 640 & - & - & 850 & - & - \\
7 & 430 & - & - & 1790 & - & - \\
9 & 810 & - & - & 1330 & - & \\
\hline Mean & 680 & - & & $1090 \pm 370$ & $390 \pm 140$ & $140 \pm 30$ \\
\hline
\end{tabular}

deviation from the mean were calculated for all skeletal muscles together. According to the STUDENT t-test the difference between skeletal muscles and heart muscle appeared to be highly significant $(\mathrm{P}<0.00 \mathrm{I})$. The $\mathrm{P}$-value for the difference between skeletal muscles and diaphragm muscle was also smaller than o.oor. As a consequence of the small number of determinations in extracts from stomach muscle and diaphragm muscle it was only possible to conclude from the means and their standard deviations that the difference between heart and stomach muscle $(\mathrm{P}<0.02)$, between heart and diaphragm muscle $(\mathrm{P}<0.0 \mathrm{I})$, between stomach muscle and diaphragm muscle $(\mathrm{P}<0.05)$, and between skeletal muscle and stomach muscle $(\mathrm{P}<0.0 \mathrm{r})$ were significant. As, however, the following sequence of glucolinase activities of extracts was found for each of the three rabbits in which all kinds of muscles mentioned were investigated

heart muscle $>$ skeletal muscle $>$ stomach muscle $>$ diaphragm muscle,

it may be safely concluded that highly significant differences would always have been found should larger numbers of stomach muscles and diaphragm muscles have been investigated.

The ratio of the means of the glucokinase activities of extracts was found to be skeletal muscle: heart muscle: stomach muscle: diaphragm muscle $=\mathrm{I}: \mathrm{I} .5: 0.5: 0.2$.

\section{Man}

Of human subjects, only skeletal muscles could be investigated. Samples of various muscles were excised from patients undergoing an operation, but not suffering from muscle diseases. Immediately after excision the samples were transported from the Surgical Clinic to the laboratory in a container cooled with ice. Just as was found for rabbit muscles, the results, assembled in Table III, do not give evidence of differences existing between various skeletal muscles.

As no significant differences could be detected between various skeletal muscles, either in the rabbit or in man, pooling of various skeletal muscles of one individual of smaller species, necessary in order to obtain sufficient material $(2 \mathrm{~g})$ for a determination, seems permissible.

References p. 473 . 
TABLE III

GLUCOKINASE ACTIVITY OF EXTRACTS FROM NORMAL HUMAN MUSCLES

\begin{tabular}{l|c}
\hline \multicolumn{1}{c|}{ Muscle } & GU per g tissue \\
\hline Serratus anterior & I230 \\
Serratus anterior & I310 \\
Serratus anterior & I020 \\
Serratus anterior & I040 \\
Serratus anterior & I220 \\
Serratus anterior & I030 \\
Erector trunci & I000 \\
Vastus lateralis & I 450 \\
\hline \multicolumn{1}{c|}{ Mean } & I $160 \pm \mathrm{I} 20$ \\
\hline
\end{tabular}

Rat

It was necessary to pool the hearts of three to six rats for each determination.

The extracts of the leg muscles of 21 rats had a glucokinase activity of $1360 \pm 170$ GU per $g$ muscle, while the results of the determination in one group of 3 hearts and in two groups of 6 hearts were I950, I780, and r950 GU respectively, with a mean value of $\mathrm{I} 890 \pm 90 \mathrm{GU}$ per g. Hence also in this case the difference between skeletal muscle and heart muscle is highly significant $(\mathrm{P}<0.00 \mathrm{I})$. The ratio of the average activities of heart muscle and skeletal muscle extracts was I.4.

\section{Guinea-pig}

The leg muscles and the hearts of ten guinea-pigs were examined. It was necessary to pool the hearts of every two animals. The results are assembled in Table IV. The difference between both kinds of muscles appeared to be highly significant $(\mathrm{P}<0.00 \mathrm{r})$. The ratio of the mean activities of heart and leg muscle extracts was I.6.

\section{Chicken}

The results obtained with leg muscle, breast muscle and heart are given in Table V. The difference between breast muscle and leg muscle was not significant, while the differences between breast muscle and heart muscle, and between leg muscle and heart muscle were highly significant and significant in the order mentioned. The ratio of the means of heart muscle and leg muscle was I.9.

Comparison of the species mentioned shows that the ratio of the activities of heart extracts and skeletal muscle extracts is fairly constant. Extracts from skeletal muscles of the rat and of man are significantly more active than those obtained from skeletal muscles of the guinea-pig, the rabbit and the chicken.

\section{Pigeon}

Breast muscle, leg muscle and heart muscle were investigated. The results were so irregular that a full description does not seem justified. Roughly, the group of 50 pigeons investigated could be divided into three sub-groups, Ist, pigeons yielding extracts with activities more or less similar to those of the muscles of the other species investigated; and, pigeons, from which muscle extracts were obtained which were inactive or in which small amounts of glucose were formed during the ro minutes' incubation at $27^{\circ} \mathrm{C}$; 3 rd, pigeons, from which muscle extracts were obtained forming large amounts 
TABLE IV

GLUCOKINASE ACTIVITY (GU PER G TISSUE) OF EXTRACTS FROM NORMAL MUSCLES OF THE GUINEA PIG

\begin{tabular}{|c|c|c|}
\hline $\begin{array}{c}\text { Guinea pig } \\
\text { No. }\end{array}$ & Leg & Heart \\
\hline $\begin{array}{l}\mathbf{I} \\
2\end{array}$ & $\begin{array}{r}1080 \\
860\end{array}$ & I Igo \\
\hline $\begin{array}{l}3 \\
4\end{array}$ & $\begin{array}{l}880 \\
850\end{array}$ & I 620 \\
\hline $\begin{array}{l}5 \\
6\end{array}$ & $\begin{array}{r}1040 \\
930\end{array}$ & I 520 \\
\hline $\begin{array}{l}7 \\
8\end{array}$ & $\begin{array}{l}760 \\
95^{\circ}\end{array}$ & I $35^{\circ}$ \\
\hline $\begin{array}{r}9 \\
\text { 10 }\end{array}$ & $\begin{array}{l}810 \\
880\end{array}$ & I 760 \\
\hline Mean & $910 \pm 100$ & $1490 \pm 23^{\circ}$ \\
\hline
\end{tabular}

TABLE V

GLUCOKINASE ACTIVITY (GU PER G TISSUE) OF EXTRACTS FROM NORMAL MUSCLES OF THE CHICKEN

\begin{tabular}{c|c|c|c}
\hline $\begin{array}{c}\text { Chicken } \\
\text { No. }\end{array}$ & Back & Leg & Heart \\
\hline $\mathrm{I}$ & 510 & 870 & $\mathbf{1 6 1 0}$ \\
2 & 600 & 370 & 1500 \\
3 & 690 & 1300 & $\mathbf{1} 860$ \\
4 & 640 & 990 & $\mathbf{1 7 8 0}$ \\
\hline Mean & $610 \pm 80$ & $890 \pm 380$ & $\mathbf{1 6 9 0} \pm 170$ \\
\hline
\end{tabular}

of glucose during incubation. No evidence for the decomposition of synthesized glucosephosphate by tissue phosphatase could be obtained. It seems probable that certain pigeon muscle extracts contain some inhibitor of the glucokinase.

\section{Atrophic muscles}

In 5 rabbits the sciatic nerve in one of the hind legs was severed. In another rabbit the femoral nerve of this leg was also cut.

Severance of the sciatic nerve causes atrophy of the gastrocnemius, severance of the femoral nerve brings about atrophy of the quadriceps femoris. After three to four weeks the animals were sacrificed and extracts prepared from the atrophied muscles as well as from the non-atrophied homologous muscles of the other leg. The results are assembled in Table VI. It will be clear from these figures that severance of a nerve 
causes a considerable increase of the activity of the extract prepared from the muscle. The difference between the means is significant $(\mathrm{P}<0.0 \mathrm{I})$, and in every case the extract prepared from the atrophied muscle showed a higher activity than the extract prepared from the homologous muscle of the other leg.

TABLE VI

GLUCOKINASE ACTIVITY (GU PER G) OF EXTRACTS FROM NORMAL AND ATROPHIC LEG MUSCLES OF THE RABBIT (ATROPHY CAUSED BY DENERVATION)

\begin{tabular}{c|c|c|c}
\hline $\begin{array}{c}\text { Rabbit } \\
\text { No, }\end{array}$ & Muscle & Normal & Atrophied \\
\hline & Gastrocnemius & 320 & $133^{\circ}$ \\
2 & Gastrocnemius & 900 & I530 \\
3 & Gastrocnemius & 430 & I280 \\
4 & Gastrocnemius & 810 & I 190 \\
5 & Quadriceps femoris & 530 & I8Io \\
& Gastrocnemius & 680 & 900 \\
6 & Gastrocnemius & 130 & 660 \\
& & $550 \pm 270$ & $1240 \pm 380$ \\
\hline
\end{tabular}

Only four human patients, suffering from various muscle diseases, could be investigated. The cause of the atrophy and the results of the determinations are given in Table VII. These figures should be compared with the figures pertaining to normal human muscles assembled in Table III. The activity of the extracts prepared from atrophied muscles appeared to be significantly lower than that of the extracts prepared from normal muscles $(\mathrm{P}<0.001)$.

TABLE VII

GLUCOKINASE ACTIVITY OF EXTRACTS FROM ATROPHIC HUMAN MUSCLES

\begin{tabular}{|c|c|c|}
\hline Muscle & Disease & GU per $g$ \\
\hline $\begin{array}{l}\text { Peroneus } \\
\text { Quadriceps femoris } \\
\text { Quadriceps femoris } \\
\text { Deltoideus }\end{array}$ & $\begin{array}{l}\text { Infantile paralysis } \\
\text { Atrophy by inactivity } \\
\text { Myotony } \\
\text { Progressive muscle atrophy }\end{array}$ & $\begin{array}{l}500 \\
630 \\
520 \\
410\end{array}$ \\
\hline & Mean & $520 \pm 90$ \\
\hline
\end{tabular}

The difference observed between atrophy in the case of the rabbits caused by severance of the nerve and atrophies occurring in human patients is quite impressive. We believe that this difference may be explained by the different rates at which the atrophies have developed, and the time during which they have existed. In the rabbits the atrophy has developed in the course of three to four weeks; the loss of weight must be chiefly attributed to loss of contractile protein. We might presume that the amount of an enzyme in the muscle has not yet been adapted to the diminished need of the inactivated muscle and has remained practically constant. If so, the amount of such an enzyme, e.g. glucokinase, per unit of mass will be increased, which is in agreement with the observations. 
The atrophy in the human patients, however, had developed slowly and had existed for years. In these cases the performance of the muscle is strongly diminished, so it may be that the enzyme system has been adapted to these conditions, resulting in a low amount of enzyme per unit of mass.

\section{DISCUSSION}

It may be stressed that no efforts have been made to determine the amounts of glucokinase present in the muscles. Only the rate of disappearance of glucose added to muscle extracts has been studied. This rate has been called the activity of the extracts, and is not only determined by the amount of glucokinase present, but also by activators and inhibitors. In particular the results obtained with pigeon muscles demonstrate that inhibitors may play a preponderant role in determining the activity of an extract.

Nevertheless, there are fairly strong indications that the determinations carried out in extracts of muscles do correspond to the amount of glucokinase they contain, viz., the fairly constant ratio of the activities of heart and skeletal muscle, the significant differences between skeletal muscles of various species, and the differences observed between normal and atrophied muscle.

Two remarks should be made regarding the method used. The extraction has been performed by adding $3 \mathrm{ml}$ water per $\mathrm{g}$ of muscle. When $\mathrm{I} \mathrm{ml}$ or $2 \mathrm{ml}$ water were used instead of $3 \mathrm{ml}$ the same activity per $\mathrm{g}$ of muscle was found (see Table VIII), from which one may conclude that the extraction of the enzyme is complete with the amounts of water used.

\section{TABLE VIII}

INFLUENCE OF VOLUME OF WATER, USED FOR EXTRACTION OF MUSCLE, ON THE OBSERVED GLUCOKINASE ACTIVITY PER G MUSCLE

Rat muscle; $\mathrm{I}: \mathrm{p}=$ extraction of $\mathrm{I} g$ muscle with $\mathrm{p} \mathrm{ml}$ water $(\mathrm{p}=\mathrm{I}, 2$ and 3 )

\begin{tabular}{|c|c|c|c|c|c|c|c|}
\hline \multirow[b]{2}{*}{$\begin{array}{c}\text { Experiment } \\
\text { No. }\end{array}$} & \multicolumn{2}{|c|}{ I : I } & \multicolumn{2}{|c|}{$I: 2$} & \multicolumn{2}{|c|}{ I : 3} & \multirow{2}{*}{$\begin{array}{l}\text { Ratio of } \mathrm{GU} \text { per } \mathrm{g} \text { muscle } \\
\text { for extraction } \\
\text { with } \mathrm{I}, 2 \text { and } 3 \mathrm{ml} \text { water } \\
\text { per } \mathrm{g} \text { muscle }\end{array}$} \\
\hline & $\begin{array}{c}\mathrm{GU} \\
\text { pero. } 8 \mathrm{ml} \\
\text { extract }\end{array}$ & $\begin{array}{c}\text { GU } \\
\text { per g } \\
\text { muscle }\end{array}$ & $\begin{array}{c}\text { GU } \\
\text { per } 0.8 \mathrm{ml} \\
\text { extract }\end{array}$ & $\begin{array}{c}\text { GU } \\
\text { per g } \\
\text { muscle }\end{array}$ & $\begin{array}{c}\mathrm{GU} \\
\text { pero.8 ml } \\
\text { extract }\end{array}$ & $\begin{array}{c}\text { GU } \\
\text { perg } \\
\text { muscle }\end{array}$ & \\
\hline I & $47^{\circ}$ & 1050 & 330 & I I $5^{\circ}$ & 200 & 980 & $0.9: 1.0: 0.9$ \\
\hline 2 & 700 & 1570 & 460 & I 610 & 310 & $I_{45^{\circ}}$ & I. $0: 1.0: 0.9$ \\
\hline 3 & $53^{\circ}$ & 1190 & 280 & 980 & 190 & 9 IO & I. $2: 1.0: 0.9$ \\
\hline 4 & 580 & 1320 & $33^{\circ}$ & I I 60 & 210 & rooo & I.I : I.O:0.9 \\
\hline 5 & 510 & I I $4^{\circ}$ & 300 & 1030 & 200 & 980 & I.I:I.O:0.9 \\
\hline
\end{tabular}

However, this also implies that the effect of inhibitors, if present, would run parallel with the concentration of the enzyme, which does not seem to be very likely. So in our opinion the results obtained by extracting with different amounts of water increase the probability that, in the extracts of rat muscle at least, the influence of inhibitors is of minor importance.

As has been remarked in the section on the preparation of the extracts, it is not permissible to dilute the extracts after they have been separated from the muscle debris. Table IX shows the results of two experiments in which the original extract was compared with diluted extracts (I vol. extract + I vol. water and I vol. extract +2 vol. water).

References p. 473 . 
TABLE IX

INFLUENCE OF DILUTION ON GLUCOKINASE ACTIVITY OF RAT MUSCLE EXTRACTS Undiluted extract obtained by extracting a $\mathrm{g}$ muscle with $3 \mathrm{a} \mathrm{ml}$ water

\begin{tabular}{l|c|c}
\hline \multirow{2}{*}{ Dilution } & \multicolumn{2}{|c|}{ GU per $0.8 \mathrm{ml}$} \\
\cline { 2 - 3 } & Ist exp. & 2nd exp. \\
\hline & 590 & 500 \\
Undiluted extract & I20 & 30 \\
I vol. extract + r vol. water & 50 & ro \\
I vol. extract + 2 vol. water & & \\
\hline
\end{tabular}

The ratio of the activities should be $6: 3: 2$, but the observed ratios were 6.0:I.2:0.5 and 6.0:0.4:0.0 respectively. So we see that upon dilution the decrease of activity does not correspond with the dilution, but is more rapid. We can offer no explanation for this dilution effect.

\section{SUMMARY}

The glucokinase activity of extracts of muscles of various species (man, rabbit, guinea-pig, rat and chicken) has been determined.

The activity of an extract prepared from a rabbit muscle, which had atrophied in the course of three to four weeks as a consequence of severance of the nerve, was always much higher than the activity of the extract prepared from the homologous normal muscle. On the other hand the average activity of extracts from atrophied human muscles was about half the average activity of extracts prepared from normal human skeletal muscles. This difference between atrophy caused by severance of the nerve and atrophy caused by disease might be explained by the difference in rate of development and in time during which the atrophy has existed.

\section{RÉSUME}

Nous avons déterminé l'activité glucokinasique d'extraits de muscles de différentes espèces (homme, lapin, cobaye, rat et poule).

L'activité d'un extrait d'un muscle de lapin atrophié au cours de trois à quatre semaines par suite de la disjonction du nerf, était toujours plus élevée que l'activité d'un extrait préparé à partir du muscle homologue normal. D'autre part, l'activité moyenne d'extraits de muscles atrophiés humains était environ la moitié de l'activité d'extraits préparés à partir de muscles striés humain normaux. Cette différence entre l'atrophie causée par disjonction du nerf et l'atrophie causée par maladie pourrait être expliquée par la différence de vitesse de développement et de durée de l'atrophie.

\section{ZUSAMMENFASSUNG}

Die Glucokinaseaktivität von Muskelextrakten von verschiedenen Arten (Mensch, Kaninchen, Meerschweinchen, Ratte und Huhn) wurde bestimmt.

Die Aktivität eines Extraktes aus einem Kaninchenmuskel, welcher im Laufe von drei bis vier Wochen durch Nervendurchschneidung atrophierte, war immer viel höher als die Aktivität eines Extraktes, der aus einem homologen normalen Muskel hergestellt worden war. Andererseits war die durchschnittliche Aktivität von Extrakten aus atrophierten menschlichen Muskeln ungefähr die Hälfte der durchschnittlichen Aktivität von Extrakten, welche aus normalen menschlichen Skelettmuskeln hergestellt wurden. Dieser Unterschied zwischen der Atrophie durch Nervendurchschneidung und durch Krankheit könnte durch den Unterschied in der Entwicklungsgeschwindigkeit und in der Dauer der Atrophie erklärt werden.

\section{REFERENCES}

1 S. P. Colowick, G. T, Coni and M. W. Slein, J. Biol. Chem., I68 (1946) 583 .

2 E. Kun, J. Biol. Chem., I74 (1948) 761 :

3 A. L. Dounce, A. Rothstein, G. Thannhauser Beyer, R. Meyer and R. M. Freer, J. Biol. Chem., I74 (1948) $36 \mathrm{I}$.

4 K. BAILEY, Biochem. J., 45 (1949) 479.

5 V. D. Wiebelhaus and H. A. LaRdy, Arch. Biochem., 2 I (1949) 32 I. 